\title{
1 Title: Potential biomarker of human papillomavirus 16 L1 \\ 2 methylation for prediction of anal intraepithelial neoplasia in men 3 who have sex with men (MSM)
}

4 Arkom Chaiwongkot ${ }^{1,2^{*}}$, Nittaya Phanuphak ${ }^{3}$, Tippawan Pankam ${ }^{3}$, Parvapan Bhattarakosol ${ }^{1,2}$

$5{ }^{1}$ Applied Medical Virology Research Unit, Faculty of Medicine, Chulalongkorn University,

6 Bangkok 10330, Thailand.

$7 \quad{ }^{2}$ Department of Microbiology, Faculty of Medicine, Chulalongkorn University, Bangkok 10330,

8 Thailand.

$9 \quad{ }^{3}$ The Thai Red Cross AIDS Research Centre, Bangkok 10330, Thailand.

$10{ }^{*}$ Corresponding author: Arkom Chaiwongkot, Ph.D.

11 Division of Virology, Department of Microbiology,

12 Faculty of Medicine, Chulalongkorn University

131873 Rama 4 Road, Patumwan,

14 Bangkok 10330, Thailand

15 E-mail: arkomchaiwongkot@gmail.com

16

17 Short title: Potential biomarker of HPV16 L1 methylation in MSM with anal intraepithelial

18 neoplasia 


\section{Abstract}

21 Quantitative measurement of human papillomavirus (HPV) 16 early promoter and L1 genes

22 methylation were analyzed in anal cells collected from men who have sex with men (MSM) to

23 determine the potential biomarker for screening of HPV related anal cancer. The methylation

24 patterns of the HPV16 genes including early promoter (CpG 31, 37, 43, 52 and 58) and L1 gene

25 (CpG 5600, 5606, 5609, 5615, 7136 and 7145) were analyzed in 178 anal samples with histology

26 diagnosed as normal, anal intraepithelial neoplasia (AIN) 1, AIN2 and AIN3 by pyrosequencing

27 assay. Low methylation levels of early promoter $(<10 \%)$ and L1 genes $(<20 \%)$ were found in all

28 detected normal anal cells, while medium to high methylation (>20-60\%) in early promoter was

29 found $1.5 \%(1 / 67)$ and 5\% (2/40) in AIN1 and AIN2-3 samples, respectively. Interestingly,

30 slightly increased L1 gene methylation level (>20-60\%) especially at HPV16 5'L1 regions CpGs

315600 and 5609 from normal to AIN3 were demonstrated. Moreover, negative correlation between

32 high HPV16 L1 gene methylation at CpGs 5600, 5609, 5615 and 7145 and low percentage of

33 CD4+ was found in AIN3 HIV positive cases. When compared methylation status of AIN2-3 to

34 those of the normal/AIN1 lesion, the results indicated potential of using HPV16 L1 gene

35 methylation as a biomarker for HPV related cancer screening. 


\section{Introduction}

39 Anal carcinoma is a rare disease found in men and women population globally with average

40 incidence of $<1-2$ per 100,000[1]. However, the incidence of anal cancer was high in HIV infected

41 women and HIV-infected men who have sex with men (MSM), accounting for 30/100,000 and

$42131 / 100,000$, respectively [2] .There is association between human papillomavirus (HPV) infection

43 and anal carcinoma in which HPV DNA was found in men (68.7-91.2\%) and women (90.4-90.9\%)

44 with anal carcinoma worldwide [3]. Studies showed that HPV16 was predominantly detected in

45 men and women, accounting for $70-71.6 \%$ and $74-83.4 \%$, respectively $[2,4,5]$.

46 High prevalence of HPV infection was reported in anal cells collected particularly from HIV

47 infected MSM. Worldwide HPV prevalences in anal cells of HIV infected and HIV uninfected

48 MSM were $92.6 \%$ and $63.9 \%$, respectively and HPV16 was found $35.4 \%$ and $12.5 \%$ in general

49 HIV infected and HIV uninfected MSM, respectively [6]. Recent study in China reported high

50 prevalence of HPV infection among HIV-infected MSM (82.69\%) compared with HIV uninfected

51 MSM (62.81\%)[7]. In Bangkok, Thailand, anal HPV infection was found $85 \%$ in HIV infected

52 MSM compared with 58.5\% in HIV infected MSM in which HPV16 was detected 22.5\% and 9.8\%

53 in HIV infected and HIV uninfected MSM, respectively [8]. The prevelance of anal HPV infection

54 in northern Thailand was $80 \%$ among MSM, in which $100 \%$ and $70 \%$ were found in HIV infected

55 MSM and HIV uninfected MSM, respectively, HPV16 was the most common high risk types,

56 accounting for $40 \%$ in HIV infected MSM and 22\% in HIV uninfected MSM [9]. It was reported

57 that HPV16 was the most persistent high risk HPV types [10] and less likely to have spontaneous

58 regression from cervical intraepithelial neoplasia (CIN)2-3 to normal when compared to other

59 HPV types $[11,12]$. The study in HIV uninfected MSM revealed that HPV16 showed the longest

60 duration of infection with the lowest rate of viral clearance when compared to low risk HPV [13].

61 High risk HPV is considered to be the causative agent of cervical cancer and other HPV related

62 cancers such as vulva, head and neck cancer and anal. Viral oncoproteins E6 and E7 disrupt

63 normal function of host proteins involved in cell cycle regulation such as E6 causes p53 
64 degradation and E7 inactivates retinoblastoma protein[14, 15]. However, the development of HPV

65 related cancers takes more than 10-20 years, while the majority of HPV infected population has

66 spontaneous regression [16, 17]. Up-regulation of viral E6 and E7 oncoproteins and down

67 expression of viral proteins involved in viral particle assembly such as L1/L2 proteins are

68 correlated with cancer progression[18, 19]. Epigenetic modification such as methylation of HPV

69 genome is considered to be one factor to control the expression of viral genes during productive

70 and transforming infections.

71 Differential methylation in HPV16 genome has been reported in cervical samples, during

72 productive infection. HPV16 early promoter was found unmethylated in basal and intermediate

73 cells at proximal E2 binding sites 2-4 (E2BS) but became highly methylated in superficial cells at

74 the upper part of the epithelium. In latent HPV16 infection, viral long control region (LCR)

75 including early promoter was highly methylated throughout the epithelium. In transforming

76 HPV16 infected cells, the distal E2BS (E2BS1) and enhancer regions were found to be methylated,

77 while the early promoter was unmethylated [20]. One study showed that HPV16 p670 late

78 promoter was highly methylated in cervical carcinoma cases [21]. The low expression of viral

79 early gene and lack of capsid L1/L2 proteins expression in undifferentiated basal cells could

80 prevent activation of immune response to viral infection [22].

81 The methylation pattern in early promoter especially HPV16 E2BS has been widely studied in

82 cervical cells and the methylation patterns were reported either progressive hypomethylation [23,

$8324]$ and progressive hypermethylation [21, 25, 26]. One study showed that high methylation of

84 E2BS was correlated with episomal form in high grade cervical lesions, cervical carcinoma and

85 multiple copies of integrated HPV genome [27]. L1 gene hypermethylation was correlated with

86 severe cervical lesions and cervical carcinoma [28-30]. We have previously reported the

87 association between high methylation of HPV16 L1 gene especially at CpG site 5600 and 5609

88 and high grade cervical lesions and cervical carcinoma [31]. However, there are limited studies of

89 HPV16 genome methylation in anal cells especially in Asian countries. This study aimed to detect

90 methylation pattern of HPV16 in early promoter and L1 regions in anal cells obtained from Thai 
91 MSM, analyzed by quantitative pyrosequencing assay. The pattern of methylation revealed the

92 potential of using methylation at specific site as biomarker for screening of high-grade lesions of

93 anal squamous intraepithelial cells.

\section{Materials and methods}

\section{Clinical samples and cell lines}

96178 HPV16 positive DNA samples extracted from anal cells were collected from men who having

97 sex with men (MSM) at the Thai Red Cross AIDS Research Centre (TRC-ARC) Bangkok,

98 Thailand. There were 134 HIV positive cases and 44 HIV negative cases. Percentage of CD4+

99 results were obtained only from HIV positive men. DNA extracted from human cervical cancer

100 cell lines containing of integrated HPV 16; CaSki, (CRL-1550 Lot No.3794357) containing

101 approximately 500-600 copies per cell) and SiHa (HTB-35 Lot No.4031219) containing 1-2 copies

102 per cell were used as positive control for amplification and pyrosequencing. This study has been

103 approved (COA No. 053/2016) by the Institutional Review Board of the Faculty of Medicine,

104 Chulalongkorn University.

\section{Methylation analysis by Pyrosequencing}

106 The extracted DNA (100-1000 ng) from anal cells was bisulfite conversion by using EZ kit Gold

107 Bisulfite Conversion Kit (Zymo Research) according to the manufacturer's instruction. The

108 sequences of forward, reverse and sequencing primers for early promoter CpG positions 31, 37,

10943,52 and 58, 3'L1 CpG positions 7136 and 7145 and 5'L1 CpG positions 5600, 5606, 5609 and

1105615 were shown in Table 1. 
115 Table 1 The sequences of forward and reverse primers used in this study

\begin{tabular}{|c|c|c|c|}
\hline Target gene & Nucleotide sequences & Size (bp) & Reference \\
\hline $\begin{array}{l}\text { Early promoter: } \\
\text { CpG } 31,37,43,52,58\end{array}$ & $\begin{array}{l}\text { FW: 5'-TTGTAAAATTGTATATGGGTGTG-3' } \\
\text { RV: Biotin-5'-AAATCCTAAAACATTA CAATTCTC-3' } \\
\text { Sequencing primer } \\
\text { 400S1: 5'-AATTTATGTATAAAATTAAGGG-3' }\end{array}$ & 192 & [32] \\
\hline $\begin{array}{l}\text { 3'L1: CpG } 7136 \text { and } \\
7145\end{array}$ & $\begin{array}{l}\text { FW: Biotin-5'-GGTTAAATTAAAATTTATATTAGGAAAA-3' } \\
\text { RV: 5'-AAACATATACACAACAAACAACACTAATTC-3' } \\
\text { Sequencing primer } \\
\text { 800: 5'- TACATACAATACTTACAACT-3' }\end{array}$ & 140 & [31] \\
\hline $\begin{array}{l}\text { 5'L1: } \quad \text { CpG } 5600, \\
5606,5609,5615\end{array}$ & $\begin{array}{l}\text { FW Biotin 5'-TAATATATAATTATTGTTGATGTAGGTGAT -3' } \\
\text { RV 5'-AACAATAACCTCACTAAACAACCAAAA-3' } \\
\text { Sequencing primer } \\
\text { 5600: 5'-CCAAAAAAACATCTAAAAAAAAATATAATA-3' }\end{array}$ & 130 & [31] \\
\hline
\end{tabular}

117 PCR amplification protocol was as follows: $13.6 \mu \mathrm{L}$ DNase/RNase free water, $1 \mathrm{X}$ PCR buffer,

$1182.5 \mathrm{mM} \mathrm{MgCl}_{2}, 250 \mu \mathrm{M} \mathrm{dNTP}, 12.5 \mathrm{pM}$ of each forward and reverse primers, 1 Unit DNA

119 polymerase (HotStart HiFidelity Polymerase, Affymetrix, USA). The PCR conditions were started

120 with initial denaturing at $95^{\circ} \mathrm{C}$ for 10 minutes, followed by 50 cycles of $95^{\circ} \mathrm{C}$ for 30 seconds, $55^{\circ} \mathrm{C}$

121 for 1 minute and $72^{\circ} \mathrm{C}$ for 1 minute and a cycle of final extension at $72^{\circ} \mathrm{C}$ for 10 minutes. The PCR

122 products were detected by $1.5 \%$ agarose gel electrophoresis. Prior to pyrosequencing, $20 \mu \mathrm{L}$ of

123 amplified products labeled with biotin were mixed with beads, washed, denatured, mixed with

$1240.4 \mu \mathrm{M}$ of sequencing primers and loaded into the PyroMark ${ }^{\mathrm{TM}}$ Q96 machine (Qiagen, Germany).

\section{Statistical analysis}

126 The Kruskal-Wallis test was used to analyze the differences of the mean methylation values

127 among groups of specimens. Fisher exact test was used to examine the significant differences of

128 propotion of sample with methylation $>20 \%$ between normal/AIN1 and AIN2-3. Pearson's

129 correlation coefficient (r) was used to analyse the association between percentage of methylation

130 and CD4+. $P$-value less than 0.05 was considered statistically significant difference. 


\section{Results}

\section{Methylation levels of HPV16 early promoter and L1 gene in cervical cancer cell lines}

135 Of 178 HPV16 positive samples including 134 HIV positive and 44 HIV negative samples, mean

136 age was 31.23 years. Histology results were obtained from 123 samples classified as 16 normal, 67

137 AIN1, 12 AIN2 and 28 AIN3. Methylation patterns in HPV16 early promoter and two regions

138 within HPV16 L1 gene were analyzed. The methylation levels of early promoter comprising 5

139 CpGs (31, 37, 43, 52 and 58) including proximal E2 binding sites (E2BSs) and Sp1 binding site of

140 CaSki were $70 \%, 60.5 \%, 73.5 \%, 66.5 \%, 77 \%$ and of SiHa cells were $0-1 \%$ in all $5 \mathrm{CpGs}$,

141 respectively. Methylation levels of L1 gene $(5600,5606,5609,5615,7136$ and 7145$)$ were $84 \%$,

$14259 \%, 76 \%, 65 \%, 69 \%$ and $67 \%$ for CaSki and 95\%, 96\%, 80\%, 80\%, 69\% and 76\% for $\mathrm{SiHa}$,

143 respectively, as shown in Fig 1. High methylation of L1 gene was detected in both cervical cell

144 lines regardless of copy number of integrated HPV16. 


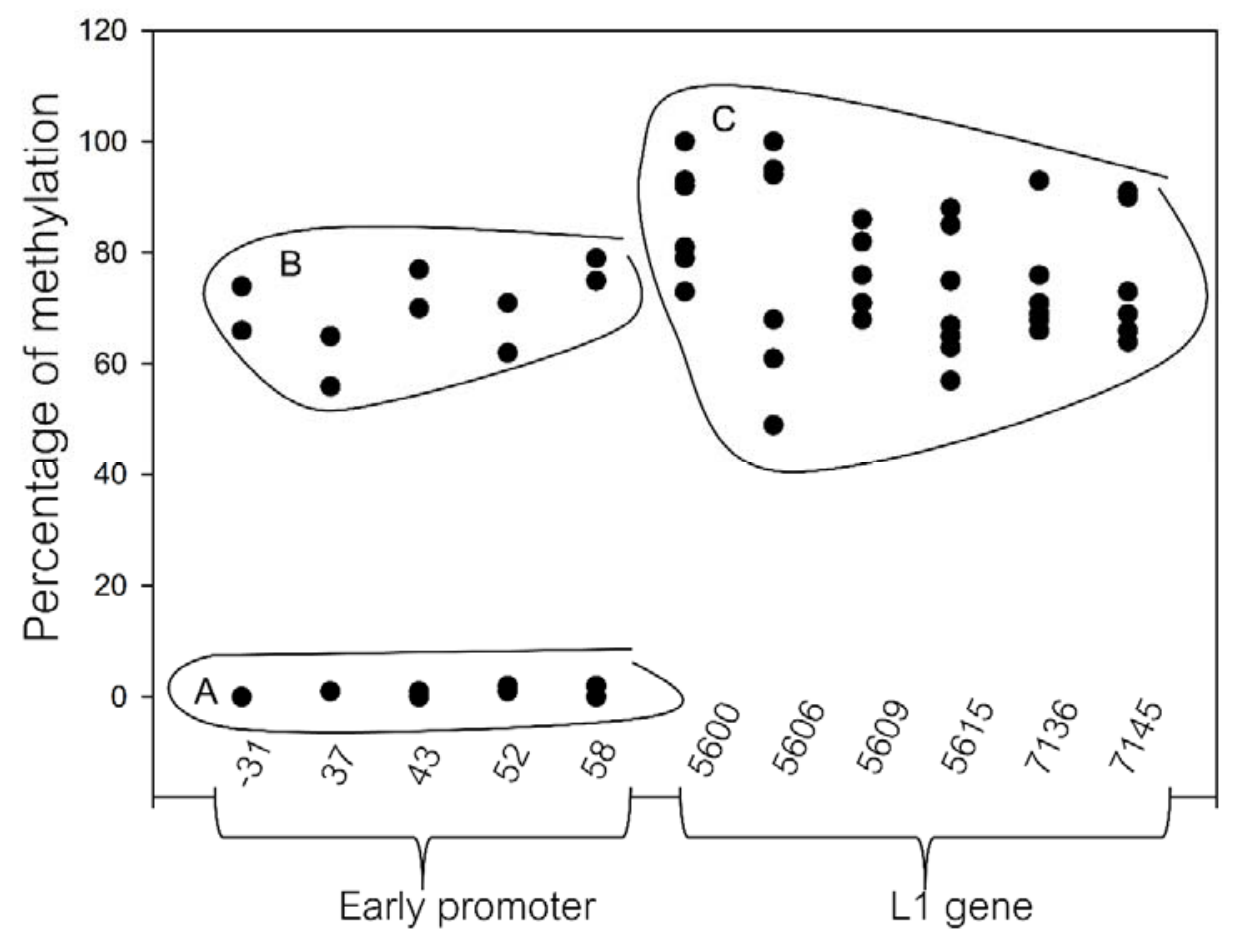

150 Fig 1. A scatter plot of methylation percentage of $11 \mathrm{CpGs}$ located within early promoter 151 (positions 31, 37, 43, 52 and 58), 3'L1 (positions 7136 and 7145), and 5'L1 regions (positions $1525600,5606,5609$ and 5615) of Caski and SiHa cell lines. A and B were methylation levels 153 obtained from SiHa and CaSki, respectively. C was methylation level of L1 gene obtained from 154 both SiHa and Caski.

\section{Methylation levels of HPV16 early promoter and L1 gene in anal cells}

156 The methylation levels of early promoter in normal, AIN1 and AIN2-3 were shown in Fig 2. The 157 methylation level was $<10 \%$ in all normal anal cells, while intermediate methylation level (20$15840 \%$ ) was found in some of AIN1 and AIN2-3. The majority of AIN1 and AIN2-3 showed low 159 methylation level in early promoter $(<10 \%)$. For L1 gene, low methylation level was found in all 160 detected normal anal cells $(<20 \%)$. There was slightly increased in L1 gene methylation from 161 normal to AIN2-3, especially at CpG5600 and 5609 which methylation levels were found in range 162 20-60\% which were higher than other CpGs (5606, 5615, 7136 and 7145) (Fig 3). Intermediate to 163 high methylation levels (20-60\%) of CpG5600 was found in 0\% (0/16) normal, 10.5\% (7/67) 
165 AIN2-3 was found in CpG5609. There was significant difference of samples number with

166 methylation percentage $>20 \%$ between normal/AIN1 $(8.4 \% ; 7 / 83)$ and AIN2-3 $(27.5 \% ; 11 / 40)$ in

167 CpG5600 (Table 2).

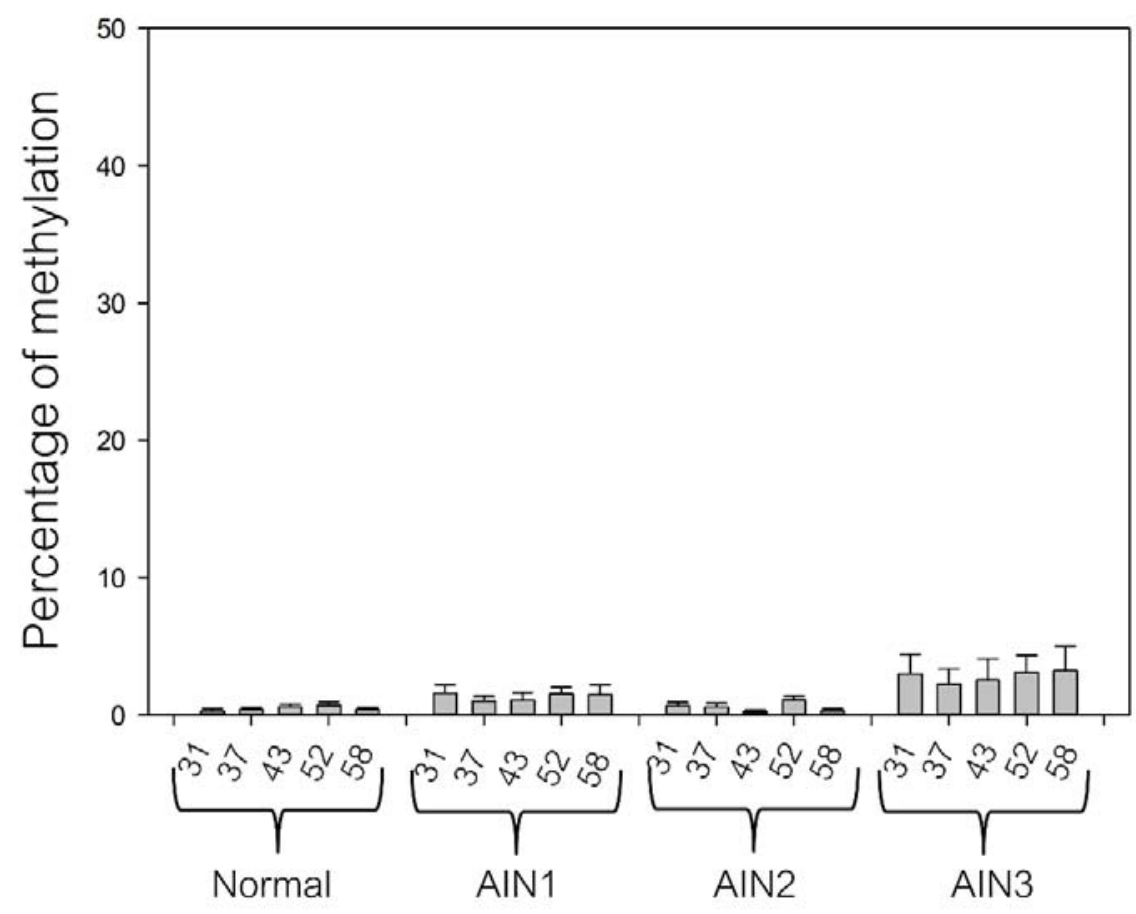

169 Fig 2. A bar graph of methylation percentage of early promoter in anal samples stratified by

histology as normal, AIN1, AIN2 and AIN3 (mean \pm SE).

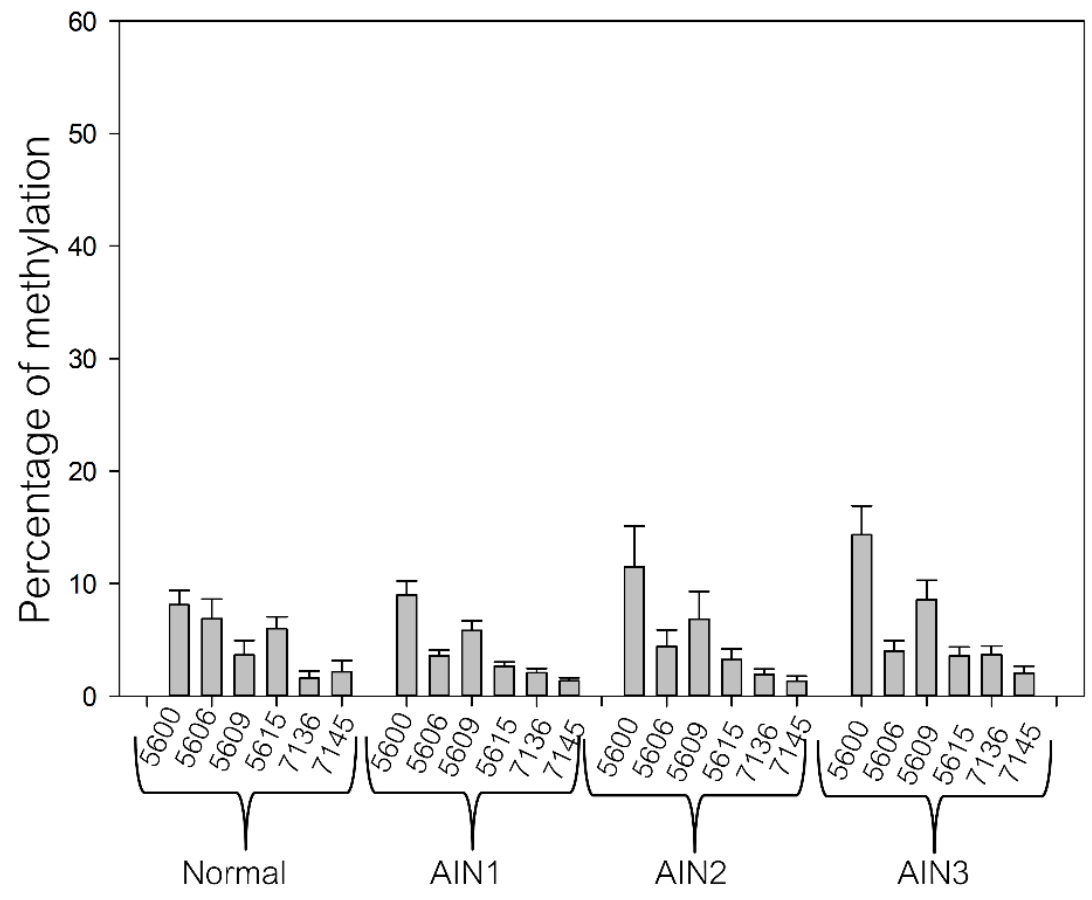


172 Fig 3. A bar graph of methylation percentage of L1 gene in anal samples stratified by histology as

173 as normal, AIN1, AIN2 and AIN3 (mean \pm SE).

175 Table 2. Subject demographic and methylation status of HPV16 early promoter and L1 genes in 176 anal cells with various grades of lesions. The $p$-values were calculated using Kruskal-Wallis test 177 and Fisher Exact test. * indicated significant difference.

\begin{tabular}{|c|c|c|c|c|c|}
\hline Group & Normal & AIN1 & AIN2 & AIN3 & $p$-value \\
\hline No. (123) & 16 & 67 & 12 & 28 & \\
\hline $\begin{array}{ll}\text { Age } & \text { (years): } \\
\text { Mean } & \\
\text { SD } & \\
\text { Range } & \end{array}$ & $\begin{array}{l}27.93 \\
6.82 \\
22-47\end{array}$ & $\begin{array}{l}31.06 \\
6.66 \\
19-50\end{array}$ & $\begin{array}{l}31.3 \\
5.66 \\
25-42\end{array}$ & $\begin{array}{l}32.52 \\
6.27 \\
22-52\end{array}$ & $>0.05$ \\
\hline $\begin{array}{l}\text { \%Methylation level: } \\
\text { CpG } \\
\text { Mean } \\
\text { SD } \\
\text { Range } \\
\% \text { samples }>20 \% \\
\% \text { samples }<20 \%\end{array}$ & $\begin{array}{l}0.300 \\
0.483 \\
0-1 \\
0 \% \\
100 \%\end{array}$ & $\begin{array}{l}1.597 \\
4.568 \\
0-34 \\
1.5 \% \\
98.5 \%\end{array}$ & $\begin{array}{l}0.667 \\
0.888 \\
0-2 \\
0 \% \\
100 \%\end{array}$ & $\begin{array}{l}3.00 \\
7.299 \\
0-28 \\
7.1 \% \\
92.9 \%\end{array}$ & $>0.05$ \\
\hline $\begin{array}{l}\text { CpG } \\
\text { Mean } \\
\text { SD } \\
\text { Range } \\
\% \text { samples }>20 \% \\
\% \text { samples }<20 \%\end{array}$ & $\begin{array}{l}0.400 \\
0.516 \\
0-1 \\
0 \% \\
100 \%\end{array}$ & $\begin{array}{l}1.016 \\
3.011 \\
0-23 \\
1.5 \% \\
98.5 \%\end{array}$ & $\begin{array}{l}0.583 \\
0.900 \\
0-3 \\
0 \% \\
100 \%\end{array}$ & $\begin{array}{l}2.269 \\
5.625 \\
0-23 \\
7.1 \% \\
92.9 \%\end{array}$ & $>0.05$ \\
\hline $\begin{array}{l}\text { CpG } \\
\text { Mean } \\
\text { SD } \\
\text { Range } \\
\% \text { samples }>20 \% \\
\% \text { samples }<20 \%\end{array}$ & $\begin{array}{l}0.600 \\
0.699 \\
0-2 \\
0 \% \\
100 \%\end{array}$ & $\begin{array}{l}1.065 \\
4.745 \\
0-37 \\
1.5 \% \\
98.5 \%\end{array}$ & $\begin{array}{l}0.250 \\
0.452 \\
0-1 \\
0 \% \\
100 \%\end{array}$ & $\begin{array}{l}2.538 \\
7.824 \\
0-31 \\
7.1 \% \\
92.9 \%\end{array}$ & $>0.05$ \\
\hline $\begin{array}{l}\text { CpG } \\
\text { Mean } \\
\text { SD } \\
\text { Range } \\
\% \text { samples }>20 \% \\
\% \text { samples }<20 \%\end{array}$ & $\begin{array}{l}0.700 \\
0.823 \\
0-2 \\
0 \% \\
100 \%\end{array}$ & $\begin{array}{l}1.532 \\
3.745 \\
0-28 \\
1.5 \% \\
98.5 \%\end{array}$ & $\begin{array}{l}1.083 \\
1.084 \\
0-3 \\
0 \% \\
100 \%\end{array}$ & $\begin{array}{l}3.115 \\
6.364 \\
0-26 \\
7.1 \% \\
92.9 \%\end{array}$ & $>0.05$ \\
\hline $\begin{array}{l}\text { CpG } \\
\text { Mean } \\
\text { SD } \\
\text { Range } \\
\% \text { samples }>20 \% \\
\% \text { samples }<20 \%\end{array}$ & $\begin{array}{l}0.400 \\
0.516 \\
0-1 \\
0 \% \\
100 \%\end{array}$ & $\begin{array}{l}1.500 \\
5.331 \\
0-41 \\
1.5 \% \\
98.5 \%\end{array}$ & $\begin{array}{l}0.333 \\
0.492 \\
0-1 \\
0 \% \\
100 \%\end{array}$ & $\begin{array}{l}3.231 \\
8.878 \\
0-35 \\
7 \% \\
93 \%\end{array}$ & $>0.05$ \\
\hline $\begin{array}{ll}\text { CpG } & 5600 \\
\text { Mean } & \\
\text { SD } & \end{array}$ & $\begin{array}{l}8.111 \\
3.887\end{array}$ & $\begin{array}{l}9.00 \\
8.976\end{array}$ & $\begin{array}{l}11.500 \\
12.494\end{array}$ & $\begin{array}{l}14.346 \\
13.069\end{array}$ & $>0.05$ \\
\hline
\end{tabular}



available under aCC-BY-NC-ND 4.0 International license.

\begin{tabular}{|c|c|c|c|c|c|}
\hline $\begin{array}{l}\text { Range } \\
\% \text { samples }>20 \% \\
\% \text { samples }<20 \%\end{array}$ & $\begin{array}{l}0-13 \\
0 \% \\
100 \%\end{array}$ & $\begin{array}{l}0-50 \\
10.5 \% \\
89.5 \%\end{array}$ & $\begin{array}{l}0-40 \\
25 \% \\
75 \%\end{array}$ & $\begin{array}{l}0-57 \\
28.6 \% \\
71.4 \%\end{array}$ & $<0.05^{*}$ \\
\hline $\begin{array}{l}\text { CpG } \\
\text { Mean } \\
\text { SD } \\
\text { Range } \\
\% \text { samples }>20 \% \\
\% \text { samples }<20 \%\end{array}$ & $\begin{array}{l}6.889 \\
5.183 \\
0-15 \\
22 \% \\
78 \%\end{array}$ & $\begin{array}{l}3.593 \\
3.616 \\
0-16 \\
0 \% \\
100 \%\end{array}$ & $\begin{array}{l}4.417 \\
5.017 \\
0-14 \\
0 \% \\
100 \%\end{array}$ & $\begin{array}{l}4.000 \\
4.699 \\
0-23 \\
3.6 \% \\
96.4 \%\end{array}$ & $>0.05$ \\
\hline $\begin{array}{l}\text { CpG } \\
\text { Mean } \\
\text { SD } \\
\text { Range } \\
\% \text { samples }>20 \% \\
\% \text { samples }<20 \%\end{array}$ & $\begin{array}{l}3.667 \\
3.841 \\
0-10 \\
0 \% \\
100 \%\end{array}$ & $\begin{array}{l}5.833 \\
6.279 \\
0-37 \\
3 \% \\
97 \%\end{array}$ & $\begin{array}{l}6.833 \\
8.537 \\
0-24 \\
16.7 \% \\
83.3 \%\end{array}$ & $\begin{array}{l}8.577 \\
8.732 \\
0-35 \\
7.1 \% \\
92.9 \%\end{array}$ & $>0.05$ \\
\hline $\begin{array}{l}\text { CpG } \\
\text { Mean } \\
\text { SD } \\
\text { Range } \\
\% \text { samples }>20 \% \\
\% \text { samples }<20 \%\end{array}$ & $\begin{array}{l}6.00 \\
3.12 \\
2-12 \\
0 \% \\
100 \%\end{array}$ & $\begin{array}{l}2.648 \\
2.789 \\
0-13 \\
0 \% \\
100 \%\end{array}$ & $\begin{array}{l}3.250 \\
3.251 \\
0-9 \\
0 \% \\
100 \%\end{array}$ & $\begin{array}{l}3.577 \\
4.032 \\
0-20 \\
3.6 \% \\
96.4 \%\end{array}$ & $>0.05$ \\
\hline $\begin{array}{l}\text { CpG } \\
\text { Mean } \\
\text { SD } \\
\text { Range } \\
\% \text { samples }>20 \% \\
\% \text { samples }<20 \%\end{array}$ & $\begin{array}{l}1.583 \\
2.193 \\
0-8 \\
0 \% \\
100 \%\end{array}$ & $\begin{array}{l}2.063 \\
2.945 \\
0-17 \\
0 \% \\
100 \%\end{array}$ & $\begin{array}{l}1.917 \\
1.621 \\
0-5 \\
0 \% \\
100 \%\end{array}$ & $\begin{array}{l}3.680 \\
3.945 \\
0-16 \\
8 \% \\
92 \%\end{array}$ & $\begin{array}{l}>0.05 \\
>0.05\end{array}$ \\
\hline $\begin{array}{l}\text { CpG } \\
\text { Mean } \\
\text { SD } \\
\text { Range } \\
\% \text { samples }>20 \% \\
\% \text { samples }<20 \%\end{array}$ & $\begin{array}{l}2.167 \\
3.460 \\
0-10 \\
0 \% \\
100 \%\end{array}$ & $\begin{array}{l}1.365 \\
2.180 \\
0-12 \\
0 \% \\
100 \%\end{array}$ & $\begin{array}{l}1.333 \\
1.557 \\
0-5 \\
0 \% \\
100 \%\end{array}$ & $\begin{array}{l}2.040 \\
3.089 \\
0-12 \\
8 \% \\
92 \%\end{array}$ & $>0.05$ \\
\hline
\end{tabular}

\section{Correlation between CD4+ percentage with HPV16 gene methylation}

180 There was no statistically differences in mean of HPV16 methylation percentage between

181 HIV negative and HIV positive cases (Table 3). Interestingly, HPV16 L1 gene high methylation

182 was moderately correlated with low percentage of CD4+ in AIN3 HIV positive cases, especially at

183 CpGs 5600, 5609, 5615 and 7145 (R=0.4692-0.5412) (Fig 4). 
bioRxiv preprint doi: https://doi org/10.1101/2021.01.07 425707; this version posted January 7.2021 . The copyright holder for this preprint (which was not certified by peer review) is the author/funder, who has granted bioRxiv a license to display the preprint in perpetuity. It is made available under aCC-BY-NC-ND 4.0 International license.

188 Table 3. Mean of HPV16 gene methylation of each CpGs, HIV status and percentage of CD4+

\begin{tabular}{|l|l|l|l|l|l|l|l|l|l|}
\hline Group & Normal (16) & \multicolumn{2}{l|}{ AIN1(67) } & \multicolumn{2}{l|}{ AIN2(12) } & \multicolumn{2}{l|}{ AIN3(28) } & $p$-value \\
\hline HIV & negative & positive & negative & positive & negative & positive & negative & positive & \\
\hline No. (123) & 4 & 12 & 18 & 49 & 2 & 10 & 1 & 27 & \\
\hline $\begin{array}{l}\text { Mean\%CD4+ } \\
\text { Mean cell } \\
\text { count NA }\end{array}$ & $\begin{array}{l}19.5 \% \\
389\end{array}$ & NA & $\begin{array}{l}16.83 \% \\
315\end{array}$ & NA & $\begin{array}{l}19.2 \% \\
359\end{array}$ & NA & $16.93 \%$ & $>0.05$ \\
\hline \% Methylation & & & & & & & & 326 & \\
\hline CpG 31 & $0 \%$ & $0.43 \%$ & $2.88 \%$ & $1.11 \%$ & $1.5 \%$ & $0.5 \%$ & $0 \%$ & $3.12 \%$ & $>0.05$ \\
\hline CpG 37 & $0 \%$ & $0.57 \%$ & $2.0 \%$ & $0.64 \%$ & $2.0 \%$ & $0.3 \%$ & $0 \%$ & $2.36 \%$ & $>0.05$ \\
\hline CpG 43 & $0 \%$ & $0.86 \%$ & $2.65 \%$ & $0.47 \%$ & $0 \%$ & $0.3 \%$ & $0 \%$ & $2.64 \%$ & $>0.05$ \\
\hline CpG 52 & $0 \%$ & $1 \%$ & $2.47 \%$ & $1.18 \%$ & $2.0 \%$ & $0.9 \%$ & $0 \%$ & $3.24 \%$ & $>0.05$ \\
\hline CpG 58 & $0 \%$ & $0.57 \%$ & $3.1 \%$ & $0.91 \%$ & $0.5 \%$ & $0.3 \%$ & $0 \%$ & $3.36 \%$ & $>0.05$ \\
\hline CpG 5600 & $10.3 \%$ & $7 \%$ & $12.33 \%$ & $7.72 \%$ & $5.5 \%$ & $12.7 \%$ & $14 \%$ & $14.36 \%$ & $>0.05$ \\
\hline CpG 5606 & $6.67 \%$ & $7 \%$ & $3.73 \%$ & $3.54 \%$ & $0 \%$ & $5.3 \%$ & $6 \%$ & $3.92 \%$ & $>0.05$ \\
\hline CpG 5609 & $7 \%$ & $2 \%$ & $8.07 \%$ & $4.98 \%$ & $1.0 \%$ & $8.0 \%$ & $10 \%$ & $8.52 \%$ & $>0.05$ \\
\hline CpG 5615 & $4.67 \%$ & $6.67 \%$ & $3.13 \%$ & $2.46 \%$ & $0 \%$ & $3.9 \%$ & $5 \%$ & $3.52 \%$ & $>0.05$ \\
\hline CpG 7136 & $3 \%$ & $1.11 \%$ & $2.5 \%$ & $1.92 \%$ & $0.5 \%$ & $2.2 \%$ & $0 \%$ & $3.83 \%$ & $>0.05$ \\
\hline CpG 7145 & $3.67 \%$ & $1.67 \%$ & $1.69 \%$ & $1.26 \%$ & $1.0 \%$ & $1.4 \%$ & $0 \%$ & $2.13 \%$ & $>0.05$ \\
\hline
\end{tabular}


A

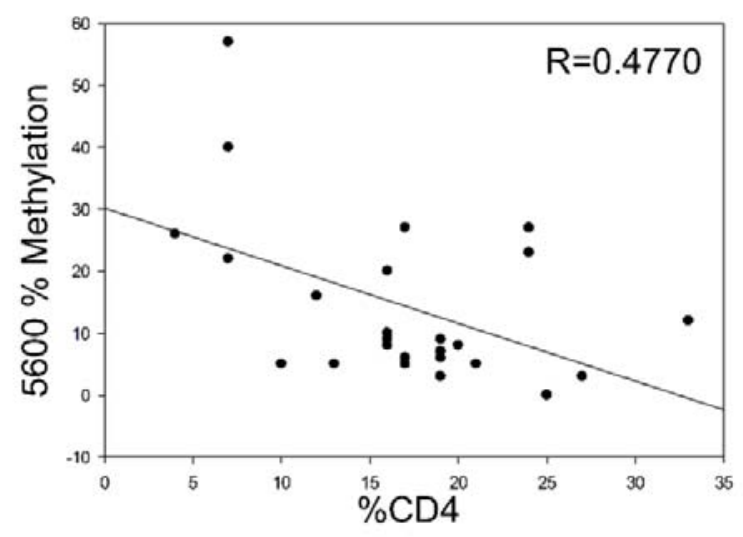

$\mathrm{C}$

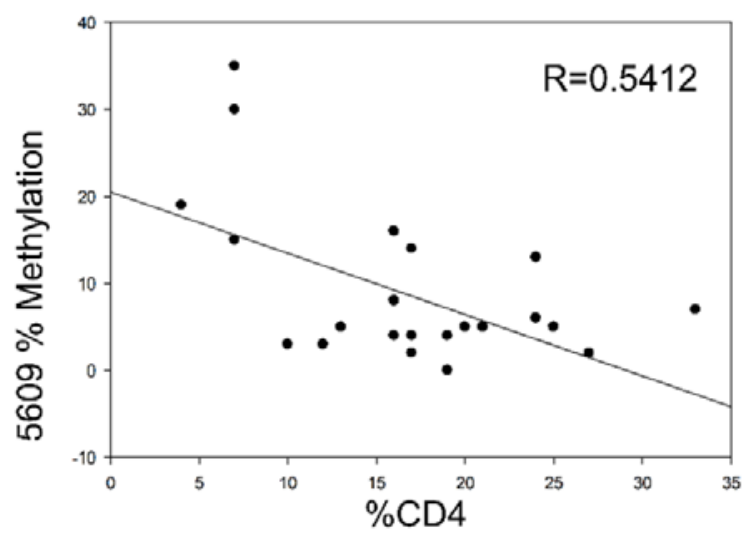

$\mathrm{E}$

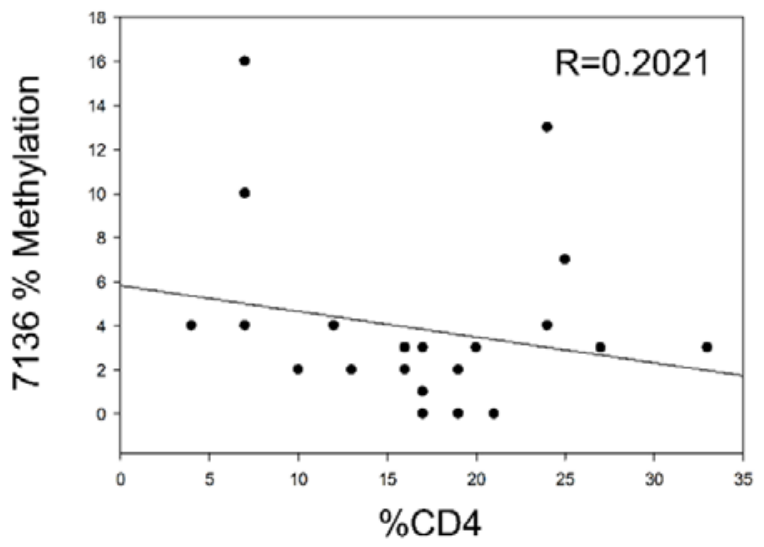

B

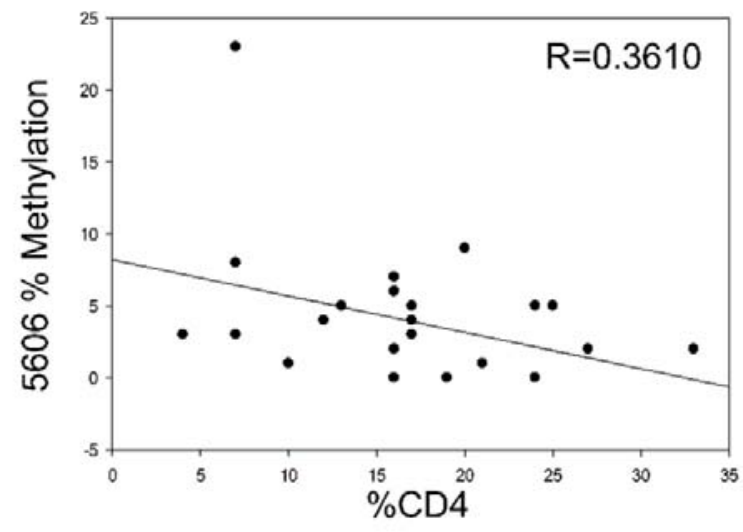

D

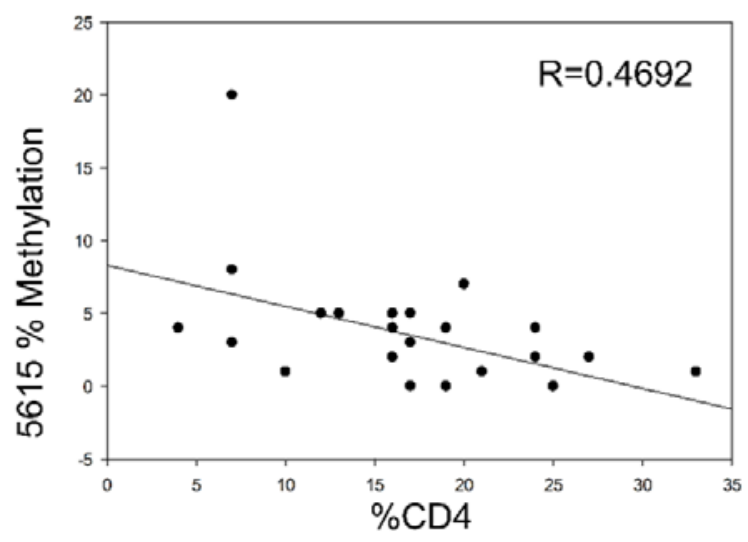

$\mathrm{F}$

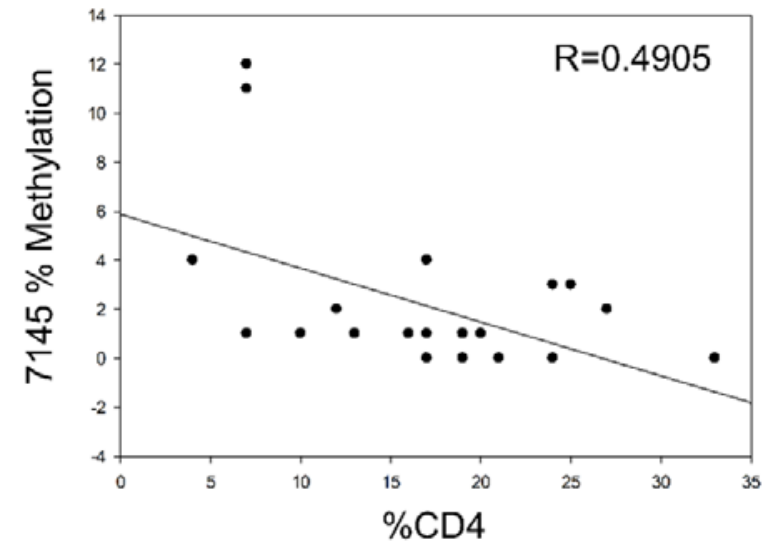

192 Fig 4. Correlation between percentage of HPV16 L1 gene methylation and number percentage of 193 CD4+ in AIN3 cases. 


\section{Discussion}

198 In the present study, the methylation pattern of HPV16 genome including early promoter region

199 and L1 gene in anal cells was studied using pyrosequencing assay. The quantitative methylation

200 analysis was first analyzed in CaSki and SiHa cell lines that methylation levels were consistent

201 with previous reports [29, 32-35]. HPV16 and 18 L1 gene hypermethylation was reported

202 previously in cervical carcinoma, vulva intraepithelial neoplasia (VIN), oral carcinoma and penile

203 carcinoma [29, 30, 36-41]. Hypermethylation in the L1 gene was found to be correlated with

204 integration form of HPV16 [38, 42]. The present study found high methylation of HPV16 L1 gene

205 in some of AIN2/3 samples compared to normal anal cells. We also found that $\mathrm{CpG}$ sites 5600 and

2065609 showed higher methylation (>20\%) compared to the other CpG sites in L1 region (5606,

207 5615, 7136 and 7145). Previous reports in cervical cells showed that CpG sites 5600 and 5609

208 were the best sites for separation of normal cervical cells and high grade dysplasia [29, 31, 43]. It

209 can be implicit that methylation patterns of HPV16 L1 gene in anal cells were similar to cervical

210 cells and might be used for separation of normal cells and HPV related severly abnormal cells.

211 Methylation patterns of HPV16 early promoter have been widely studied in cervical cells,

212 nevertheless, controversial results were found. Some studies reported hypomethylation of HPV16

213 early promoter in cervical carcinoma or so-called progressive hypomethylation [23, 24]. Other

214 studies reported hypermethylation of early promoter in cervical carcinoma or progressive

215 hypermethylation $[21,25,26,30,44]$. The physical state and copy number of integrated HPV16

216 genomes were the main reasons of these methylation differences as shown in CaSki and SiHa

217 cells. Episomal form of HPV16 genome found in high grade cervical lesions and cervical

218 carcinoma displayed high methylation levels at E2 binding sites in early promoter compared with

219 single integrated HPV16 genome [27]. One study showed high methylation of early promoter in

220 high grade anal cells [45]. We can speculate that anal samples with intermediate to high

221 methylation levels (>20\%) in the present study may be at risk to progress quickly compared to

222 those with low methylation $(<20 \%)$. 
223 It has been reported that HIV infected patients were susceptible for HPV infection. One study

224 reported that in HIV infected women with CD4+ less than 200 cells/mm3 have $59.3 \%$ of high risk-

225 HPV infections and correlated with increasing severity of cervical lesions [46]. The study in oral

226 samples reported that low CD4+ count $(<200$ cells/mm3) increased risk for oral HPV infection in

227 HIV infected patients [47]. In the present study, we could not get anal carcinoma samples due to

228 very low incidence of anal cancer. Thus, in order to employ methylation of specific CpG sites for

229 screening of HPV related cancer, a large sample size including anal carcinoma samples should be

230 further completed and evaluated.

\section{Conclusions}

232 The methylation patterns of HPV16 genome in anal intraepithelial neoplasia were similar to those

233 of cervical abnormal cells. Hypermethylation in HPV16 L1 gene especially at CpG 5600 and 5609

234 found in AIN2/3 might be used for prediction of HPV related abnormal anal cells. Moreover, high

235 HPV16 L1 gene methylation together with low CD4+ cell count in HIV infected patients may be

236 used as the biomarker for rapid progression to more severely lesions than those with low 237 methylation and high CD4+ cell count.

\section{Acknowledgments}

239 This work was supported by Research Grant for New Scholar Ratchadaphiseksomphot Endowment 240 Fund, Chulalongkorn University.

\section{References}

242 1. Flejou JF. An update on anal neoplasia. Histopathology. 2015;66(1):147-60. doi: 243 10.1111/his.12574. PubMed PMID: 25283345.

244 2. Wang CJ, Sparano J, Palefsky JM. Human Immunodeficiency Virus/AIDS, Human 245 Papillomavirus, and Anal Cancer. Surg Oncol Clin N Am. 2017;26(1):17-31. Epub 2016/11/28.

246 doi: 10.1016/j.soc.2016.07.010. PubMed PMID: 27889034; PubMed Central PMCID:

247 PMCPMC5331942.

248 3. De Vuyst H, Clifford GM, Nascimento MC, Madeleine MM, Franceschi S. Prevalence and

249 type distribution of human papillomavirus in carcinoma and intraepithelial neoplasia of the vulva, 
250 vagina and anus: a meta-analysis. Int J Cancer. 2009;124(7):1626-36. Epub 2008/12/31. doi:

251 10.1002/ijc.24116. PubMed PMID: 19115209.

252 4. Serrano B, de Sanjose S, Tous S, Quiros B, Munoz N, Bosch X, et al. Human 253 papillomavirus genotype attribution for HPVs 6, 11, 16, 18, 31, 33, 45, 52 and 58 in female 254 anogenital lesions. Eur J Cancer. 2015. Epub 2015/07/01. doi: S0959-8049(15)00491-8 255 [pii]10.1016/j.ejca.2015.06.001. PubMed PMID: 26121913.

256 5. Daling JR, Madeleine MM, Johnson LG, Schwartz SM, Shera KA, Wurscher MA, et al. 257 Human papillomavirus, smoking, and sexual practices in the etiology of anal cancer. Cancer. 258 2004;101(2):270-80. Epub 2004/07/09. doi: 10.1002/cncr.20365. PubMed PMID: 15241823.

259 6. Machalek DA, Poynten M, Jin F, Fairley CK, Farnsworth A, Garland SM, et al. Anal 260 human papillomavirus infection and associated neoplastic lesions in men who have sex with men: 261 a systematic review and meta-analysis. Lancet Oncol. 2012;13(5):487-500. Epub 2012/03/27. doi: 262 S1470-2045(12)70080-3 [pii]10.1016/S1470-2045(12)70080-3. PubMed PMID: 22445259.

263 7. Li X, Li M, Yang Y, Zhong X, Feng B, Xin H, et al. Anal HPV/HIV co-infection among 264 Men Who Have Sex with Men: a cross-sectional survey from three cities in China. Scientific 265 reports. 2016;6:21368. doi: 10.1038/srep21368. PubMed PMID: 26892938; PubMed Central 266 PMCID: PMC4759533.

267 8. Phanuphak N, Teeratakulpisarn N, Pankam T, Kerr SJ, Barisri J, Deesua A, et al. Anal 268 human papillomavirus infection among Thai men who have sex with men with and without HIV 269 infection: prevalence, incidence, and persistence. J Acquir Immune Defic Syndr. 2013;63(4):472270 9. doi: 10.1097/QAI.0b013e3182918a5a. PubMed PMID: 23514956; PubMed Central PMCID: 271 РMC3700660.

272 9. Supindham T, Chariyalertsak S, Utaipat U, Miura T, Ruanpeng D, Chotirosniramit N, et al. 273 High Prevalence and Genotype Diversity of Anal HPV Infection among MSM in Northern 274 Thailand. PloS one. 2015;10(5):e0124499. doi: 10.1371/journal.pone.0124499. PubMed PMID: 275 25932915; PubMed Central PMCID: PMC4416722.

276 10. Cho HW, So KA, Lee JK, Hong JH. Type-specific persistence or regression of human 277 papillomavirus genotypes in women with cervical intraepithelial neoplasia 1: A prospective cohort 278 study. Obstetrics \& gynecology science. 2015;58(1):40-5. doi: 10.5468/ogs.2015.58.1.40. PubMed 279 PMID: 25629017; PubMed Central PMCID: PMC4303751.

280 11. Trimble CL, Piantadosi S, Gravitt P, Ronnett B, Pizer E, Elko A, et al. Spontaneous 281 regression of high-grade cervical dysplasia: effects of human papillomavirus type and HLA 282 phenotype. Clin Cancer Res. 2005;11(13):4717-23. Epub 2005/07/08. doi: 11/13/4717 [pii]

283 10.1158/1078-0432.CCR-04-2599. PubMed PMID: 16000566; PubMed Central PMCID: 284 PMC3132609. 
285 12. Schlecht NF, Platt RW, Duarte-Franco E, Costa MC, Sobrinho JP, Prado JC, et al. Human

286 papillomavirus infection and time to progression and regression of cervical intraepithelial 287 neoplasia. J Natl Cancer Inst. 2003;95(17):1336-43. PubMed PMID: 12953088

288 13. Dona MG, Vescio MF, Latini A, Giglio A, Moretto D, Frasca M, et al. Anal human

289 papillomavirus in HIV-uninfected men who have sex with men: incidence and clearance rates,

290 duration of infection, and risk factors. Clinical microbiology and infection : the official publication

291 of the European Society of Clinical Microbiology and Infectious Diseases. 2016;22(12):1004 e1-

292 e7. doi: 10.1016/j.cmi.2016.08.011. PubMed PMID: 27585942.

293 14. Munger K, Baldwin A, Edwards KM, Hayakawa H, Nguyen CL, Owens M, et al.

294 Mechanisms of human papillomavirus-induced oncogenesis. J Virol. 2004;78(21):11451-60.

295 PubMed PMID: 15479788

296 15. Munger K, Basile JR, Duensing S, Eichten A, Gonzalez SL, Grace M, et al. Biological 297 activities and molecular targets of the human papillomavirus E7 oncoprotein. Oncogene. 298 2001;20(54):7888-98. PubMed PMID: 11753671.

299 16. Chen HC, Schiffman M, Lin CY, Pan MH, You SL, Chuang LC, et al. Persistence of type-

300 specific human papillomavirus infection and increased long-term risk of cervical cancer. J Natl 301 Cancer Inst. 2011;103(18):1387-96. doi: 10.1093/jnci/djr283. PubMed PMID: 21900119; PubMed 302 Central PMCID: PMC3176778

303 17. Moscicki AB, Shiboski S, Hills NK, Powell KJ, Jay N, Hanson EN, et al. Regression of 304 low-grade squamous intra-epithelial lesions in young women. Lancet. 2004;364(9446):1678-83.

305 Epub 2004/11/09. doi: S0140673604173546 [pii]

306 10.1016/S0140-6736(04)17354-6. PubMed PMID: 15530628.

307 18. Xiao W, Bian ML, Ma L, Liu J, Chen Y. [Detection of human papillomavirus L1 capsid 308 protein expression in liquid-based cytology samples with abnormal cytology.]. Zhonghua Fu Chan 309 Ke Za Zhi. 2009;44(12):887-91. Epub 2010/03/03. PubMed PMID: 20193413.

310 19. Origoni M, Cristoforoni P, Carminati G, Stefani C, Costa S, Sandri MT, et al. E6/E7 311 mRNA testing for human papilloma virus-induced high-grade cervical intraepithelial disease 312 (CIN2/CIN3): a promising perspective. Ecancermedicalscience. 2015;9:533. Epub 2015/05/28. 313 doi: $10.3332 /$ ecancer.2015.533

314 can-9-533 [pii]. PubMed PMID: 26015802; PubMed Central PMCID: PMC4435751.

315 20. Vinokurova S, von Knebel Doeberitz M. Differential methylation of the HPV 16 upstream 316 regulatory region during epithelial differentiation and neoplastic transformation. PloS one. 317 2011;6(9):e24451. PubMed PMID: 21915330. 
318 21. Baedyananda F, Chaiwongkot A, Bhattarakosol P. Elevated HPV16 E1 Expression Is

319 Associated with Cervical Cancer Progression. Intervirology. 2017;60(5):171-80. doi:

320 10.1159/000487048. PubMed PMID: 29495005.

22. Burley M, Roberts S, Parish JL. Epigenetic regulation of human papillomavirus

322 transcription in the productive virus life cycle. Seminars in Immunopathology. 2020;42(2):159-71.

323 doi: 10.1007/s00281-019-00773-0.

324 23. Badal V, Chuang LS, Tan EH, Badal S, Villa LL, Wheeler CM, et al. CpG methylation of 325 human papillomavirus type 16 DNA in cervical cancer cell lines and in clinical specimens: 326 genomic hypomethylation correlates with carcinogenic progression. J Virol. 2003;77(11):6227-34.

327 Epub 2003/05/14. PubMed PMID: 12743279; PubMed Central PMCID: PMC154984.

328 24. Piyathilake CJ, Macaluso M, Alvarez RD, Chen M, Badiga S, Edberg JC, et al. A higher

329 degree of methylation of the HPV 16 E6 gene is associated with a lower likelihood of being 330 diagnosed with cervical intraepithelial neoplasia. Cancer. 2011;117(5):957-63. Epub 2010/10/15.

331 doi: 10.1002/cncr.25511. PubMed PMID: 20945322; PubMed Central PMCID: PMC3023831.

332 25. Bhattacharjee B, Sengupta S. CpG methylation of HPV 16 LCR at E2 binding site 333 proximal to $\mathrm{P} 97$ is associated with cervical cancer in presence of intact E2. Virology. 334 2006;354(2):280-5. PubMed PMID: 16905170.

335 26. Ding DC, Chiang MH, Lai HC, Hsiung CA, Hsieh CY, Chu TY. Methylation of the long 336 control region of HPV16 is related to the severity of cervical neoplasia. Eur J Obstet Gynecol 337 Reprod Biol. 2009;147(2):215-20. Epub 2009/10/13. doi: 10.1016/j.ejogrb.2009.08.023

338 S0301-2115(09)00507-7 [pii]. PubMed PMID: 19819061.

339 27. Chaiwongkot A, Vinokurova S, Pientong C, Ekalaksananan T, Kongyingyoes B, 340 Kleebkaow P, et al. Differential methylation of E2 binding sites in episomal and integrated HPV 34116 genomes in preinvasive and invasive cervical lesions. Int J Cancer. 2013;132(9):2087-94. Epub 342 2012/10/16. doi: 10.1002/ijc.27906. PubMed PMID: 23065631.

343 28. Oka N, Kajita M, Nishimura R, Ohbayashi C, Sudo T. L1 gene methylation in high-risk 344 human papillomaviruses for the prognosis of cervical intraepithelial neoplasia. Int $\mathrm{J}$ Gynecol 345 Cancer. 2013;23(2):235-43. Epub 2013/01/15. doi: 10.1097/IGC.0b013e31827da1f6. PubMed 346 PMID: 23314283.

347 29. Bryant D, Tristram A, Liloglou T, Hibbitts S, Fiander A, Powell N. Quantitative 348 measurement of Human Papillomavirus type 16 L1/L2 DNA methylation correlates with cervical 349 disease grade. J Clin Virol. 2014;59(1):24-9. Epub 2013/11/26. doi: 10.1016/j.jcv.2013.10.029

350 S1386-6532(13)00477-0 [pii]. PubMed PMID: 24268385.

351 30. Fernandez AF, Rosales C, Lopez-Nieva P, Grana O, Ballestar E, Ropero S, et al. The 352 dynamic DNA methylomes of double-stranded DNA viruses associated with human cancer. 
353 Genome Res. 2009;19(3):438-51. Epub 2009/02/12. doi: 10.1101/gr.083550.108gr.083550.108

354 [pii]. PubMed PMID: 19208682; PubMed Central PMCID: PMC2661803.

355 31. Chaiwongkot A, Niruthisard S, Kitkumthorn N, Bhattarakosol P. Quantitative methylation

356 analysis of human papillomavirus $16 \mathrm{~L} 1$ gene reveals potential biomarker for cervical cancer

357 progression. Diagn Microbiol Infect Dis. 2017;89(4):265-70. doi:

358 10.1016/j.diagmicrobio.2017.08.010. PubMed PMID: 28985972.

359 32. Rajeevan MS, Swan DC, Duncan K, Lee DR, Limor JR, Unger ER. Quantitation of site-

360 specific HPV 16 DNA methylation by pyrosequencing. J Virol Methods. 2006;138(1-2):170-6.

361 PubMed PMID: 17045346.

362 33. Kalantari M, Osann K, Calleja-Macias IE, Kim S, Yan B, Jordan S, et al. Methylation of

363 human papillomavirus 16, 18, 31, and $45 \mathrm{~L} 2$ and L1 genes and the cellular DAPK gene:

364 Considerations for use as biomarkers of the progression of cervical neoplasia. Virology.

365 2014;448:314-21. Epub 2013/12/10. doi: 10.1016/j.virol.2013.10.032

366 S0042-6822(13)00607-7 [pii]. PubMed PMID: 24314662.

367 34. Lorincz AT, Brentnall AR, Vasiljevic N, Scibior-Bentkowska D, Castanon A, Fiander A, et

368 al. HPV16 L1 and L2 DNA methylation predicts high-grade cervical intraepithelial neoplasia in

369 women with mildly abnormal cervical cytology. Int J Cancer. 2013;133(3):637-44. Epub

370 2013/01/22. doi: 10.1002/ijc.28050. PubMed PMID: 23335178; PubMed Central PMCID:

371 PMC3708123.

372 35. Brandsma JL, Harigopal M, Kiviat NB, Sun Y, Deng Y, Zelterman D, et al. Methylation of 373 Twelve CpGs in Human Papillomavirus Type 16 (HPV16) as an Informative Biomarker for the 374 Triage of Women Positive for HPV16 Infection. Cancer prevention research. 2014;7(5):526-33.

375 Epub 2014/02/22. doi: 10.1158/1940-6207.CAPR-13-0354

376 1940-6207.CAPR-13-0354 [pii]. PubMed PMID: 24556390.

377 36. Kalantari M, Villa LL, Calleja-Macias IE, Bernard HU. Human papillomavirus-16 and -18

378 in penile carcinomas: DNA methylation, chromosomal recombination and genomic variation. Int $\mathrm{J}$

379 Cancer. 2008;123(8):1832-40. Epub 2008/08/09. doi: 10.1002/ijc.23707. PubMed PMID:

38018688866 ; PubMed Central PMCID: PMC2750853.

381 37. Balderas-Loaeza A, Anaya-Saavedra G, Ramirez-Amador VA, Guido-Jimenez MC, 382 Kalantari M, Calleja-Macias IE, et al. Human papillomavirus-16 DNA methylation patterns 383 support a causal association of the virus with oral squamous cell carcinomas. Int $\mathrm{J}$ Cancer. 384 2007;120(10):2165-9. Epub 2007/02/06. doi: 10.1002/ijc.22563. PubMed PMID: 17278110.

385 38. Bryant D, Onions T, Raybould R, Jones S, Tristram A, Hibbitts S, et al. Increased 386 methylation of Human Papillomavirus type 16 DNA correlates with viral integration in Vulval 
387 Intraepithelial Neoplasia. J Clin Virol. 2014;61(3):393-9. Epub 2014/09/15. doi:

388 10.1016/j.jcv.2014.08.006 S1386-6532(14)00306-0 [pii]. PubMed PMID: 25218242.

389 39. Badal S, Badal V, Calleja-Macias IE, Kalantari M, Chuang LS, Li BF, et al. The human 390 papillomavirus-18 genome is efficiently targeted by cellular DNA methylation. Virology. 391 2004;324(2):483-92. Epub 2004/06/23. doi: 10.1016/j.virol.2004.04.002

392 S0042682204002326 [pii]. PubMed PMID: 15207633.

393 40. Sun C, Reimers LL, Burk RD. Methylation of HPV16 genome CpG sites is associated with 394 cervix precancer and cancer. Gynecol Oncol. 2011;121(1):59-63. Epub 2011/02/11. doi: S0090395 8258(11)00046-1 [pii]

396 10.1016/j.ygyno.2011.01.013. PubMed PMID: 21306759; PubMed Central PMCID: 397 PMC3062667.

398 41. Turan T, Kalantari M, Calleja-Macias IE, Cubie HA, Cuschieri K, Villa LL, et al. 399 Methylation of the human papillomavirus-18 L1 gene: a biomarker of neoplastic progression? 400 Virology. 2006;349(1):175-83. Epub 2006/02/14. doi: S0042-6822(05)00858-5 [pii]

401 10.1016/j.virol.2005.12.033. PubMed PMID: 16472835.

402 42. Kalantari M, Chase DM, Tewari KS, Bernard HU. Recombination of human 403 papillomavirus-16 and host DNA in exfoliated cervical cells: a pilot study of L1 gene methylation 404 and chromosomal integration as biomarkers of carcinogenic progression. J Med Virol. 405 2010;82(2):311-20. PubMed PMID: 20029805.

406 43. Bryant D, Hibbitts S, Almonte M, Tristram A, Fiander A, Powell N. Human papillomavirus 407 type 16 L1/L2 DNA methylation shows weak association with cervical disease grade in young 408 women. J Clin Virol. 2015;66:66-71. Epub 2015/04/14. doi: 10.1016/j.jcv.2015.03.001

409 S1386-6532(15)00078-5 [pii]. PubMed PMID: 25866341.

410 44. Kalantari M, Calleja-Macias IE, Tewari D, Hagmar B, Lie K, Barrera-Saldana HA, et al. 411 Conserved methylation patterns of human papillomavirus type 16 DNA in asymptomatic infection 412 and cervical neoplasia. J Virol. 2004;78(23):12762-72. Epub 2004/11/16. doi: 78/23/12762 [pii]

413 10.1128/JVI.78.23.12762-12772.2004. PubMed PMID: 15542628; PubMed Central PMCID: 414 PMC525027.

415 45. Wiley DJ, Huh J, Rao JY, Chang C, Goetz M, Poulter M, et al. Methylation of human 416 papillomavirus genomes in cells of anal epithelia of HIV-infected men. J Acquir Immune Defic 417 Syndr. 2005;39(2):143-51. Epub 2005/05/21. doi: 00126334-200506010-00004 [pii]. PubMed 418 PMID: 15905729. 
419 46. Teixeira MF, Sabidó M, Leturiondo AL, de Oliveira Ferreira C, Torres KL, Benzaken AS.

420 High risk human papillomavirus prevalence and genotype distribution among women infected with

421 HIV in Manaus, Amazonas. Virology Journal. 2018;15(1):36. doi: 10.1186/s12985-018-0942-6.

422 47. Muller K, Kazimiroff J, Fatahzadeh M, Smith RV, Wiltz M, Polanco J, et al. Oral Human

423 Papillomavirus Infection and Oral Lesions in HIV-Positive and HIV-Negative Dental Patients. The

424 Journal of infectious diseases. 2015;212(5):760-8. Epub 02/13. doi: 10.1093/infdis/jiv080.

425 PubMed PMID: 25681375.

426

427

428

429

430

431

432

433 